DOI: $10.20472 /$ IAC.2017.031.010

\author{
ANUSHRIYA BHARGAVA \\ Pandit deendayal petroleum university, gandhinagar, India
}

\title{
E-BANKING: OPPORTUNITIES AND CHALLENGES IN INDIA
}

\begin{abstract}
:
The digital age is transforming India and its people at an unprecedented rate and level. Technology is providing ample opportunities to empower more and more individuals each day and hence, to grow endlessly. Not one sector has been left untouched by this technological revolution. The banking industry, which is considered as the backbone of any economy, has for long been governed by traditional ways and means in India. But of late, evidence suggests that e-banking has progressed in various countries, and India is no exception to this. According to one of the reports in 2014, non-cash transactions in India have surpassed 300 billion in number. With the launch of Digital India Program especially, by the P.M of India in July 2015 , a propensity to move towards digitalisation at a faster pace, and in an efficient and inclusive manner has been observed among all. Provision of e-services to all in the country through improved online infrastructure and internet penetration and connectivity lies at the heart of this Campaign.

Moreover, recently it appears that demonetisation has provided the greatest impetus to cashless transactions across all sectors in the country, including in the banking industry. Reportedly, e-banking has almost become a buzzword after this move and awareness about e-banking services and its usage have significantly increased in both rural and urban areas. In the given scenario, this paper aims to briefly trace the evolution of e-banking in India, its current status, and future opportunities and challenges, in the wake of Digital India and demonetisation, particularly.
\end{abstract}

\section{Keywords:}

E-Banking, India, Opportunities, Challenges, Digitalisation 


\section{INTRODUCTION}

\section{BANKING:}

Banking is the structural network of institutions that offer financial services within a country. The member of the banking system and the functions they typically perform include Commercial banks that take deposits and make loans, investment banks which specialize in capital market issues and trading, and the National central bank that issues currency and sets monetary policy.

\section{E BANKING:}

Electronic banking, also known as electronic funds transfer (EFT), is simply the use of electronic means to transfer funds directly from one account to another, rather than by check or cash. You can use electronic funds transfer to:

- Have your paycheck deposited directly into your bank or credit union checking account.

- Withdraw money from your checking account from an ATM machine with a personal identification number (PIN), at your convenience, day or night.

- Instruct your bank or credit union to automatically pay certain monthly bills from your accounts, such as your auto loan or your mortgage payment.

- Have the bank or credit union transfer funds each month from your checking account to your mutual fund account.

- Have your government social security benefits check or your tax refund deposited directly into your checking account.

\section{IMPORTANCE OF E - BANKING:}

E-banking helps us in overcoming the drawbacks of a manual system of banking. Other benefits are as follows:

There are many ways in which the E-banking services are helpful to the banks. They help them in increasing profits and getting competitive advantage among themselves. In promoting plastic money and E- banking also reduces the risk of Cash Overdraw. It is also beneficial to the revenue earner. As the E-banking service provides anytime and anywhere facility it reduces the rate of investment by the people on infrastructures.

E-banking services are not only helpful to the banks but they are also useful to the customers in many ways. They provide a 24-hour payment service/availability to the customers. It even gives them an ease to access any type of information regarding their account at any particular place and time. The customers even get a provision of Online 
Transactions which is much easier and safer these days.

The E-banking services are even beneficial to the merchants, traders etc in a number of ways. As the figure of the currency has been increased due to the Demonetisation the customers and the merchants face a problem of change in buying and selling things which do not possess big value. So, the E-banking service even helps in resolving this issue by enabling quick payment and settlement. It also provides international standards with low transaction cost. It eliminates almost half of the cash related problems and even helps in the growth of global and local clientele.

\section{REVIEW OF LITERATURE}

Raghavan (2006) opined that at present, more than $85 \%$ of the completed installment exchanges are an electronic and conventional method for doing saving money at the branch level has generally little significance to electronic keeping money clients. Many banks, including PSU banks, would have online ATMs, telephone saving money, virtual keeping money, e-saving money, Internet saving money, and so forth by 2020 . Mohan (2006) commented that Indian saving money is at the edge of an outlook change and a huge improvement has been accomplished by banks in offering an assortment of new and inventive e-managing account administrations to clients today, which was not considered sometime recently. In any case, open segment banks have not possessed the capacity to tackle the advantages of computerization. Kamakodi et al (2008) found that a wide hole exists in human administration in Indian saving money while innovation based administrations are surpassing desires. Respondents opined that utilizing e-keeping money for adjusting request to be the most helpful, nearly taken after by between records exchange of assets and they discovered e-managing an account minimum valuable for hotel grievances. Moderate exchange speed was observed to be the most successive issue confronted, nearly taken after by non-accessibility of the server while utilizing esaving money. Sharma (2009) opined that the pattern towards electronic conveyance of saving money items and administrations is happening somewhat therefore of buyer request, and mostly in light of the expanding aggressive condition in the worldwide setting. Kumar and Sinha (2009) referred to different cases of hacking and phishing assaults revealed all through India what's more, Shukla (2011) expressed that E-saving money offers a more elevated amount of comfort for dealing with one's accounts even from one's room. In any case, it keeps on introducing difficulties to the money related security and individual protection. Clients are exhorted not to share individual data like PIN numbers, passwords and so forth with anybody, including workers of the bank; change ATM PIN and online login and exchange passwords all the time; guarantee that the signed in session is legitimately marked out. Mishra (2011) gave valuable tips to guarantee the security of IB exchanges. IB clients are prompted not to answer to any mail, telephone call or letter, requesting the IB data like login id or secret word, and not to tap on any connection given in any mail, guaranteeing to be the connection for the bank's 
site are the essential tips, among others.

A survey of existing writing uncovers that however there is plenty of studies that inspected client's discernment about e-saving money including its notoriety and issues, concentrates that analyzed the development of e-managing an account in India in volume and esteem terms are not found.

\section{RESEARCH OBJECTIVES}

Objectives of this paper is to understand what are the challenges and opportunities of $e$ banking for the bankers, what are the opportunities and challenges of e banking for customers, What are the opportunities in e banking that bankers and customers see in context of digital india future scope and challenges of e banking, in the wake of Digital India and demonetization

\section{RESEARCH METHODOLOGY}

\section{Research Type}

We use descriptive research and exploratory research design in our studies. Descriptive research is also called Statistical Research. The main goal of this type of research is to describe the data and characteristics about what is being studied. The idea behind this type of research is to study frequencies, averages, and other statistical calculations. Descriptive research is used to obtain information concerning the current status of the phenomena to describe "what exists" with respect to variables or conditions in a situation. The methods involved range from the survey which describes the status quo, the correlation study which investigates the relationship between variables, to developmental studies which seek to determine changes over time.

\section{Data Collection}

Primary Data: Structured Questionnaire

Secondary Data: Online Database

Sampling: The study's objective was accomplished through the collection and analysis of primary data obtained from a purposive sampling technique. Likert scale questionnaire was used to measure the perception of customers about e- banking. Members of the population are chosen based on their relative ease of access. To sample relatives, friends, businessman, bankers, govt. employees are all examples of convenience sampling. 


\section{EVOLUTION OF E-BANKING IN INDIA}

Since the late 1990s E-Banking has developed from virtual insignificance to tens of millions of users worldwide (OECD, 2001). In India e-banking is the recent origin. Only in the early 1990s, there has been starting of non-branch banking services. The opening up of the economy in 1991 marked the entry of foreign banks. They brought new technology with them. Banking products became more and more competitive. Need for differentiation of products and services was felt. The good old manual systems on which Indian Banking depended upon for centuries seem to have no place today. The credit of propelling web keeping money in India goes to ICICI Bank. Citibank and HDFC Bank took after with the web keeping money benefits in 1999.

A few activities have been taken by the Legislature of India and the Save Bank to encourage the advancement of $\mathrm{E}$ saving money in India. The Administration of India instituted the IT Demonstration, 2000 with impact from October 17, 2000, which gave lawful acknowledgment to electronic exchanges and different methods for electronic trade. The Save Bank is checking and investigating the lawful and different necessities of e-depending on a persistent premise to guarantee that e-saving money would create on sound lines and e-managing account related difficulties would not represent a risk to budgetary dependability. A high-level Committee under the chairmanship of Dr. K.C. Chakrabarty and members from IIT, IIM, IDRBT, Banks and the Reserve Bank prepared the "IT Vision Document- 2011-17", for the Reserve Bank and banks which provide an indicative roadmap for enhanced usage of IT in the banking sector. To cope with the pressure of growing competition, Indian commercial banks have adopted several initiatives and $E$ banking is one of them. The opposition has been particularly intense for people in general area banks, as the recently settled private segment and remote banks are pioneers in the appropriation of e-keeping money. Electronic Clearing Administration (ECS) was propelled in the 1990s to take into account mass and dreary installments. By September 2008, another symbol as National Electronic Clearing cell was propelled to deal with various credits to recipient accounts. National Electronic Clearing Administration (NECS) rides on center keeping money arrangement of part banks. The retail supports exchange framework was acquainted in the 1990s with permit electronic exchange of reserve for individuals to individual installment.

In November 2005, a robust system was launched to allow one to one fund's transfer requirement of individuals and corporate. Prepaid instruments allow transaction for goods and services against the value stored on payment instrument. It may be in the form of smart cards, magnetic stripe cards, internet wallets, mobile accounts, mobile wallets and paper vouchers. Consequent to the guidelines in mobile banking, selected banks were permitted to offer the service after receipt of necessary permission from Reserve Bank of India. Indian Retail payments pose significant challenges and opportunities. Based on Payment system vision document released by Reserve Bank of India, the number of non- 
cash transactions, at 6 per person, is low in India. It is estimated that Government subsidies alone constitute more than Rs.2.93 trillion and electronification has a potential to translate 4.13 billion electronic transactions in a year. Based on the report of Internet and Mobile Association of India (IAMAI), Internet commerce is expected to reach Rs.465 billion by the year 2012 .

\section{CURRENT TRENDS IN E-BANKING (BANKERS' VIEW)}

\section{How do you let your customers know about the E-Banking services you provide?}

According to a survey of bankers, bankers guide to their customer through different advertisement like radio, newspaper, online, etc and they also gave guidance through their official site and print media. But the most popular way is bank official who gave guidance to their customer's face to face and solves their problems. According to this survey, 44.4\% bankers thought that their customer knows their $E$ banking service through their official. $11.1 \%$ bankers thought that their customer knows their $E$ banking service through different advertisement.

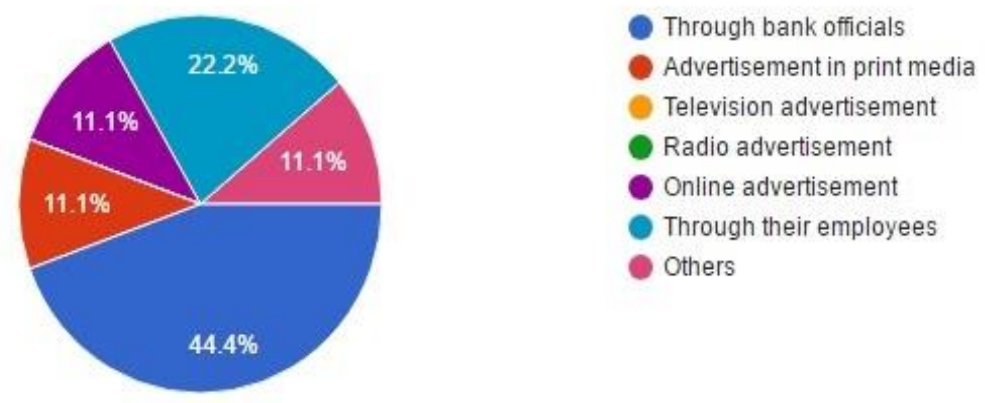

Figure 1: Customers know about E-Banking service bankers provide

\section{What are the methods you use to encourage the clients of your bank to use E- Banking?}

Bankers use different ways to encourage their client to use $E$ banking services. Banks arrange a seminar for their client so they know what the $E$-banking service is and what are the benefits of the service. $38.9 \%$ bankers thought that their clients encourage through their technological knowledge to customer through seminar.27.8\% bankers giving them a guarantee of security and privacy of their online transaction. 


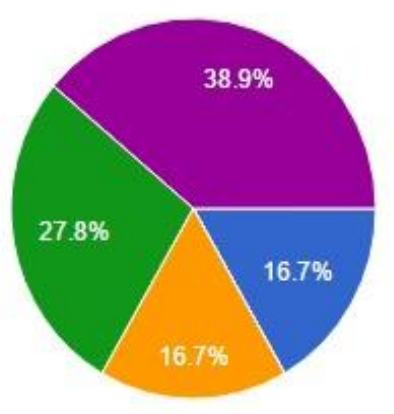

Make them cheaper by reducing charges and fees

Incentive advertisement

Customer personality

Giving them guarantee of security and privacy

- Giving the technological knowledge to customer through seminar

Figure 2: The methods which bankers use to encourage their bank client to use EBanking.

\section{Most of the customers don't know how to use and aren't aware of some E-Banking services provided by their banks.}

According to the survey, the customer does not know how to use and aren't aware of some $\mathrm{E}$ - banking services provided by their banks. $72.2 \%$ bankers thought that customer aren't aware of E banking services. It was a challenge which was facing by the bankers because of customer afraid of the using $E$ banking service. They are also afraid of the security problem.

But nowadays government of India introduced the project Digital India so people are going to use e banking service. The government has also organized different campaigns and seminars so that people become more aware and use e-banking services.

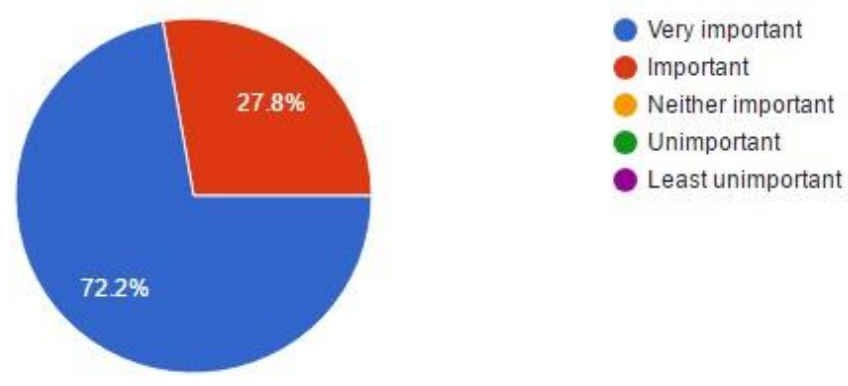

Figure 3: the customers don't know how to use and aren't aware of some E-Banking services provided by their banks.

E-Banking services are generally faster than traditional banking which helps customers to avoid long queue in the banking hall.

Bankers thought that $E$ banking service is faster than traditional banking which helps to avoid long queue in the banking hall. We use $\mathrm{E}$ banking service anywhere everywhere 
and we also paid all the bills online. We also use the $E$ banking services in corporate offices, malls, and online tickets booking. In past, E banking service is not popular so the people can't use the services which were provided by their banks. $66.7 \%$ bankers have strongly agreed that $E$ banking services are faster than traditional banking. With the help of Digital India, the banks also provide many offers for using $E$ banking services.

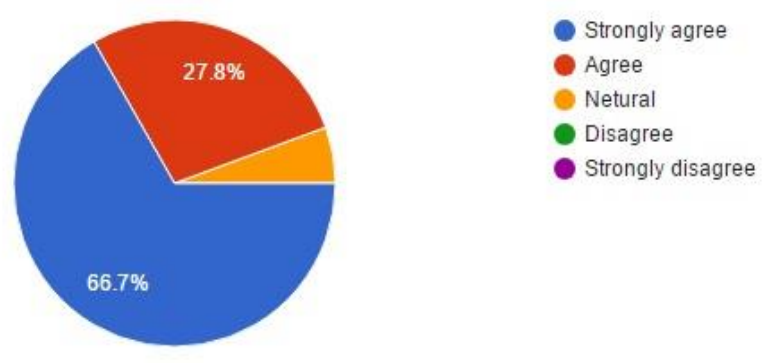

Figure 4: E-Banking services are generally faster than traditional banking

\section{The cost of adopting is very high.}

The Business Transformation Program is being implemented by the Bank which will provide its customer convenience banking on a $24 \times 7$ basis in India and abroad with integrated delivery channels like the Internet, Phone, Mobile, and others. Bank charges a high rate of the service which was provided by their Bank so people are not using more services. $61 \%$ bankers thought that the customer not using internet banking services that much because the bank charged a high rate for providing their internet services.

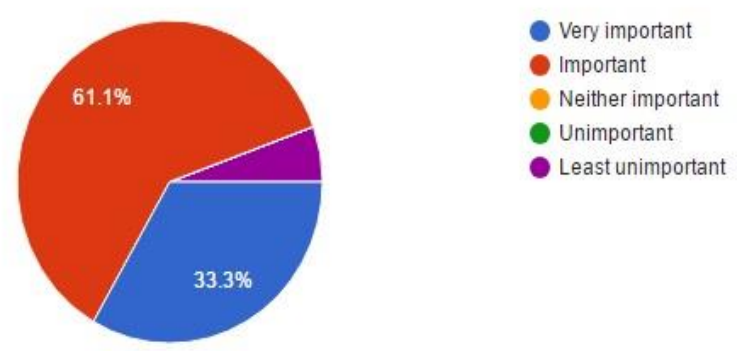

Figure 5: The cost of adopting is very high

\section{Traditional banking still remains the best option for our clients.}

People are not using E banking service because there is no security; there is trust issue, and also the internet speed service effect to the customer mentality. And in a remote area, people don't trust on internet banking so they prefer traditional banking service. In 
this period the people thought that traditional banking was safe because they believe in face to face conversation. In India, there is no legal term for the internet banking so people are more afraid of using internet services for fund transfer, taking a loan, take account statement etc. So these all the challenges were facing by the bankers. But in the last 2 years, the people have been using internet services because of Digital India campaign. With the help of Digital India people are aware of the internet services and their benefits. Young generation uses the $\mathrm{E}$ banking service more but seniors do not trust on the $\mathrm{E}$ banking service they always prefer traditional banking.

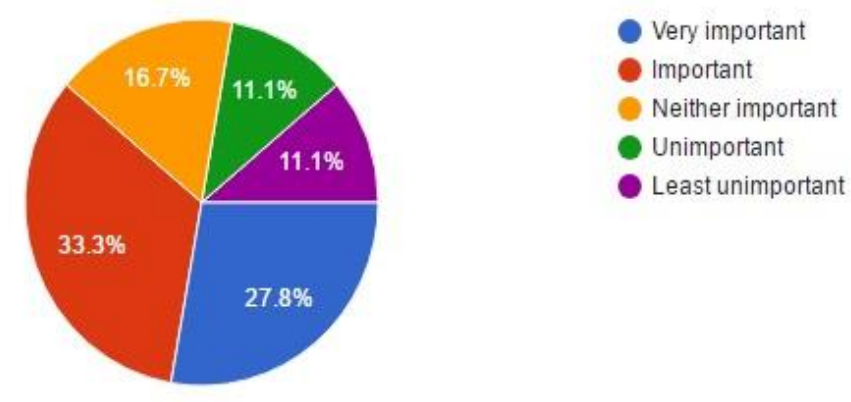

Figure 6: Traditional banking still remains the best option for our clients.

\section{Lack of infrastructure is the main problem.}

There is no particular infrastructure for $E$ banking services. Infrastructure is an important element of the $E$ banking, without which $E$ Banking would not be feasible. Hence, it is important for every bank. $83 \%$ bankers agreed with this statement they also felt that in India there was a lake of $E$ banking infrastructure. Bankers thought that that was one the most important challenge for the banks and bankers also.

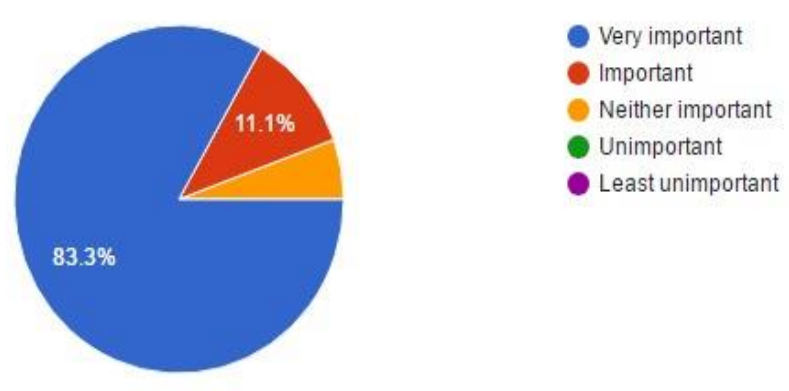

Figure 7: Lack of infrastructure is the main problem

Fear of absence of proper laws and regulations regarding E-banking. 
In Indian constitution, there were no particular law and regulation for the $E$ banking service. There is no proper act for the internet banking. There is no concrete legal mechanism to deal with robbery. These criminal cases are then resolved under existing unspecialised laws. So people are afraid of that because there are no proper laws and regulations for the internet banking.

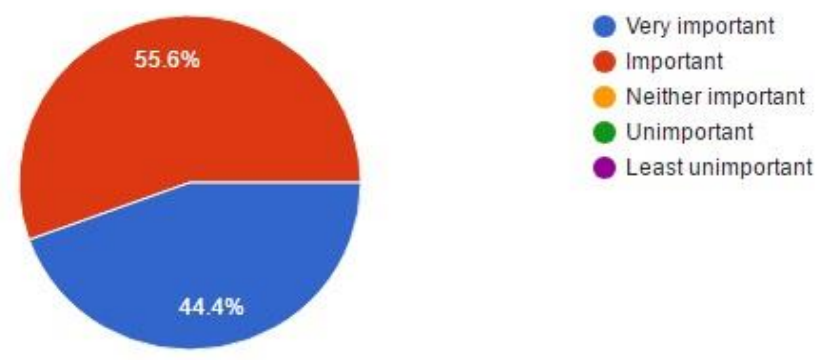

Figure 8: Fear of absence of proper laws and regulations regarding E-banking.

Fear of risk management challenges like reputation risk, operational and capital adequacy risk.

Banks has a risk of their reputation because they were provided the internet service. Sometimes there are operational problems comes so people always point out the banks. So there is management challenges like reputation risk, operational and capital adequacy risk. Every bank has a risk of their reputation.

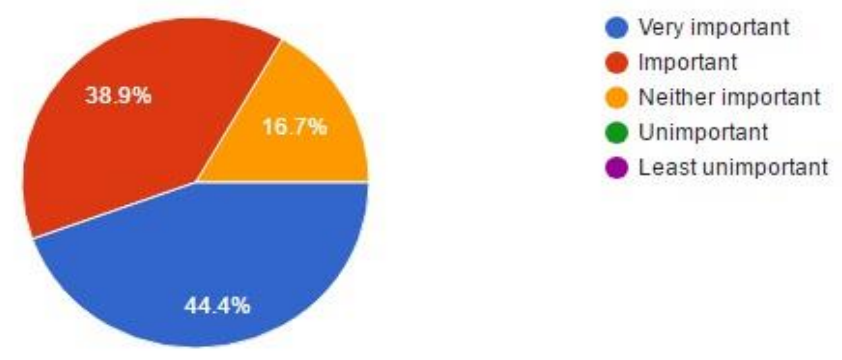

Figure 9: Fear of risk management challenges.

\section{E-Banking service is more profitable than traditional Banking services.}

E banking services are more profitable because $E$ banking service using anywhere and anytime. $\mathrm{E}$ banking service is more profitable than traditional banking because banks provide some offer for using $E$ banking services. Customers attracted to the offer which was provided by their banks for using $E$ banking. 50\% bankers thought that $E$ banking service is more profitable than traditional banking services. 


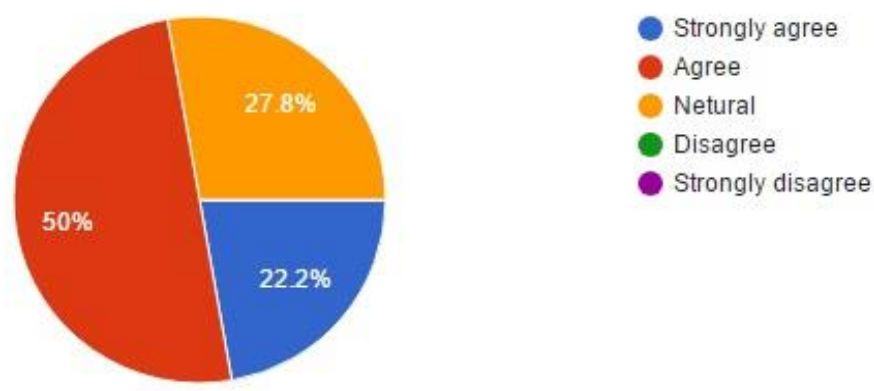

Figure 10: E-Banking service is more profitable than traditional Banking services.

E-Banking may help in avoiding many risks like robbery in physical handling of a large amount of cash.

E banking avoids many risks like robbery in physical handling amount. In traditional banking, there was a risk of the robbery. In an online transaction, there is no risk of the robbery so internet banking was safe. The customer can transfer the fund with the help of NEFT, RTGS, and transfer of funds from one account to another account. So E banking service is more secure than traditional banking. That's why $E$ banking is important for the transaction and the transfer of funds because $E$ banking may help in avoiding many risks like robbery in physical handling of a large amount of cash.

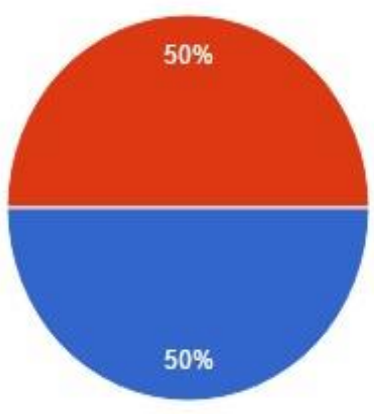

Strongly agree

Agree

Netural

Disagree

Strongly disagree

Figure 11: E-Banking may help in avoiding many risks.

\section{CURRENT TRENDS IN E-BANKING (CUSTOMERS VIEW)}

Nowadays, customers are using different services of $E$ banking. A customer is using his/her bank's application for checking their account balance, paying any bills, for booking tickets, changing their password, transfer funds, etc. The young generation is using $E$ banking service mostly because it knows the importance of $E$ Banking in daily life. The young generation is using $E$ banking service because it understands the current trends 
and they also know the concept of Digital India. People are also facing internet problems in remote areas.

\section{E-Banking services have no time limit since I can use them at any time of the day.}

E banking service has no limit for use. You can use E banking service anytime and anywhere. It is important because there is no limit for the using. 53.5\% customer thought that it was important for using services. There were so many services which were provided by their banks so you can easily use it. You can pay bills anytime, transfer funds anytime anywhere, you can also change the password. These all facilities are provided by the banks.
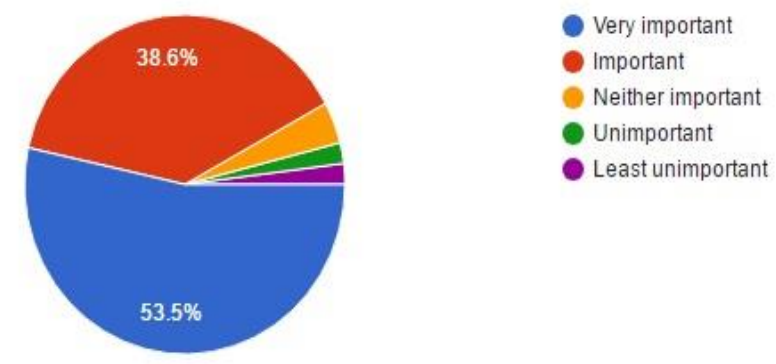

Figure 12: E-Banking services have no time limit since I can use them at any time of the day.

\section{Most of the customers are not aware of E-Banking services provided by banks.}

Customers are not using $E$ banking service because of they not aware of their banking service. The customer always refers the traditional banking because that was secure. In the remote area, the customer not aware of their services which were provided by their bank but for banks always organized the seminar so their customer aware of their services and use it instead of traditional banking. Bankers always gave an information about the Digital India objective which was related to $E$ banking. The government of India also arrange the different campaign and seminar for spreading the awareness of $E$ banking in digital banking.

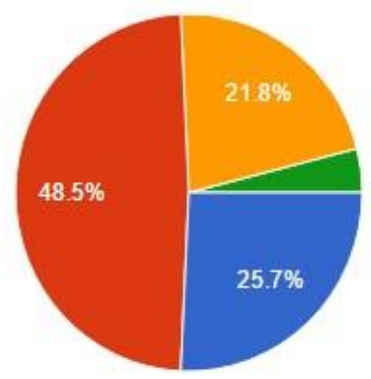


Figure 13: the customers are not aware of E-Banking services

\section{Some banks charge high fees for using E-Banking service.}

There are so many banks which provided different services like Money transfer, Bill payment, RTGS, NEFT, Bank Statement Funds transfer, account inquiry, etc. Every bank charges the fees for providing internet services. Every bank has their own rates for the services which were provided by the bank, and their charges are dependent on their strategies and the number of facilities and their customer. According to the survey, $48.5 \%$ customer has not adopted their E banking services because they charge high.

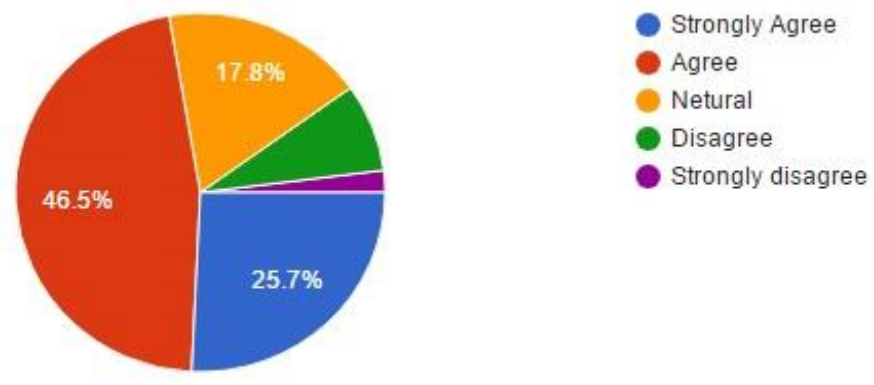

Figure 14: Some banks charge high fees for using E-Banking service.

\section{E-Banking channels are easier to use than traditional channels.}

E Banking services are easier to use than traditional channels because there is no time wasting for the fund transfer and other facilities. With the help of $E$ banking channels customer can easily use their any service at anytime anywhere. So E banking is very important for the fund transfer. In traditional banking, the customer can go and stand in the queuing at bank hall. If a customer using traditional banking so there is a risk like a robbery in physical handling of a large amount of cash. So $E$ banking is very safe for the transfer large amount.
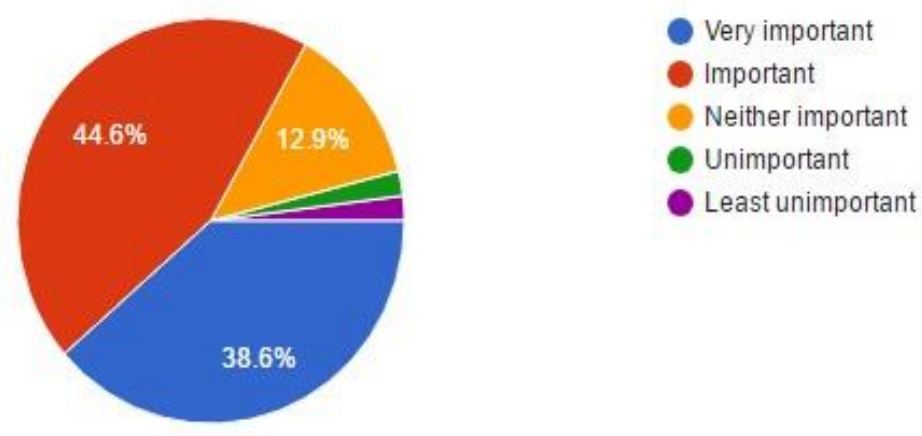

Figure 15: $\mathrm{E}$-Banking channels are easier to use than traditional channels.

Security concerns are the most discouraging factor in using E-Banking services. 
There is a most important challenge for the $E$ banking in the context of the customer is security because there is no term and conditions for the $E$ banking in the Indian constitution.This factor is discouraging in using $E$ banking services. There were no legal term and regulations for the internet banking. $41 \%$ customer thought that security concerns are the most discouraging factor in using $E$ banking services.

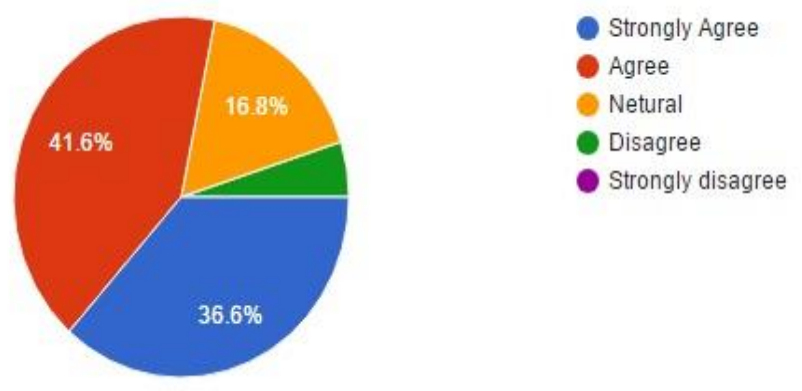

Figure 16: Security concerns is the most discouraging factor

\section{Most of the customers prefer traditional banking.}

Most of the customers prefer traditional banking because in traditional banking there is security for the customers. So customers thought that traditional banking is more secure than E baking, and this is the big challenge for the bank. In India, people thought that the traditional banking is safe because every transaction did by face to face. In the remote area, the people mostly prefer traditional banking because they are afraid of the $E$ banking services. So in India, most of the customers prefer traditional banking

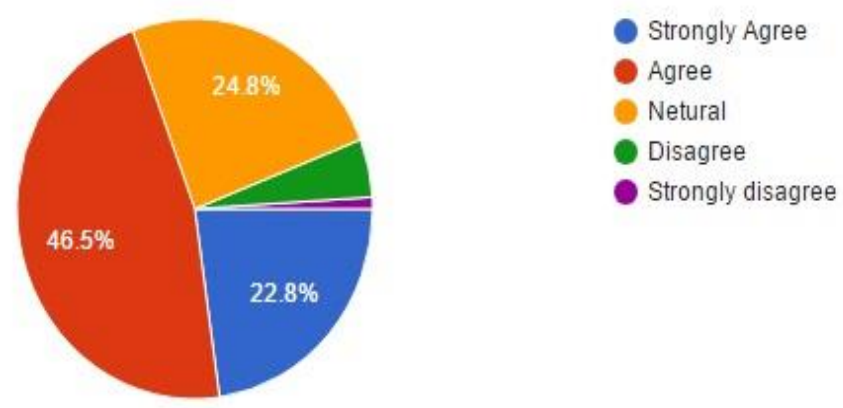

Figure 17: Most of the customers prefer traditional banking.

\section{Less mobile and internet penetration in remote areas}

In a remote area, internet network problem is a big issue for the people. In remote areas, people are not using $E$ banking services because they can't use smart mobile that much. In a remote area, people are not aware of internet banking and their services. 


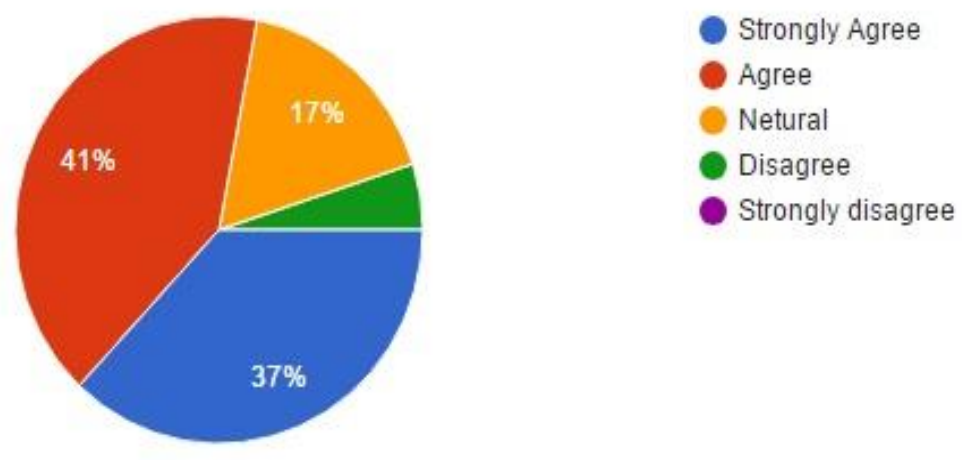

Figure 18: Less mobile and internet penetration in remote areas.

\section{CONCLUSION}

\section{OPPORTUNITIES AND CHALLENGES FOR E BANKING}

Innovation is a scaffold undoubtedly, an extension that interfaces the expectation that India's towns will be instructed and mindful to the chance of web and access to data from over the world. 'Computerized India' is not only an activity but rather a requirement for this nation, where dominant part of the populace still does not approach the universe of the web. The Digital India activity tries to lay accentuation on governance and change India into a carefully engaged society.

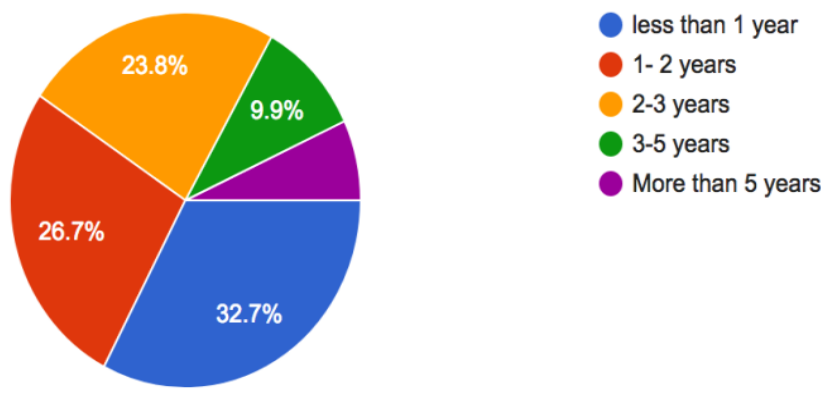

Figure 17: Since when have you been using E-Banking services

Indian Prime Minister Narendra Modi rightly said in his speech in San Jose, "I see technology as a means to empower and as a tool that bridges the distance between hope and opportunity. Social media is reducing social barriers. It connects people on the strength of human values, not identities." With development and expansion of technology and their users, e-banking has proved to be a boon for the consumers. The Digital India initiative seeks to lay emphasis on e-governance and transform India into a digitally 
empowered society. It is to ensure that government services are available to citizens electronically. More than $60 \%$ people have started using e-banking in last 2 year. With the help of digital india, people are more aware of the $E$ banking service and they started using $E$ banking services in last 2 years and them also aware of their opportunities.

The customer can take advantage from the using of e banking services. They use the different services like fund transfer, online shopping, payment of bills, etc. In Digital India, there are so many campaigns which were held by the government of india and different banks so people easily use their services from their banks with a lower rate and with different offers. Approx $50 \%$ customer thought that E-Banking service was more prestigious than queuing at bank hall.

\section{Challenges for the customer:}

There are so many challenges which were faced by the customer. Security concerns are the most discouraging factor in using E-Banking services. Wheather poor or rich, every person around wants to feel secure and look for its comfort level. Money plays an important role in everyone's life. Because security was a big issue on the customer's side, $41 \%$ customer thought that security is important when we use $E$ banking services. In the low, there are no legal terms for the online banking so people are more afraid of the internet banking. Most of the customers are not aware of E-Banking services provided by banks.

Other challenges: a) E-channels are creating more confusion to the customer.

b) E-bank service charges are high (hidden cost).

c) Smart card sometime creates technical hurdles to make payments.

d) Unauthorized access to the network and loss or damage of data by hackers

e) Inaccurate processing of transactions and transaction has not been uploaded.

f) Data privacy and confidentiality.

g) A significant problem with network connection.

h) Lack of knowledge regarding use of E-channels

\section{Challenges for the bankers:}

The challenges related to e-banking from the banker's context are discussed below: 
The Trust Factor: Trust is the biggest hurdle to online banking for most of the customers. Conventional banking is preferred by the customers because of lack of trust on the online security. They have a perception that online transaction is risky due to which frauds can take place. While using e-banking facilities lot of questions arises in the mind of customers such as: Did transaction go through? Did I push the transfer button once or twice? Trust is among the significant factors which influence the customer's willingness to engage in a transaction with web merchants.

Security Risk: The problem related to the security has become one of the major concerns for banks a large group of customers refuses to opt for e-banking facilities due to uncertainty and security concerns According to survey $44.4 \%$ of internet users are not using Internet banking in India because of security concerns. So it's a big challenge for bankers and makes consumers satisfied regarding their security concerns, which may further increase the online banking use.

Privacy risk: The risk of disclosing private information \& fear of identity theft is one of the major factors that inhibit the consumers while opting for internet banking services. Most of the consumers believe that using online banking services make them vulnerable to identity theft. According to the study consumers" worry about their privacy and feel that bank may invade their privacy by utilizing their information for marketing and other secondary purposes without the consent of consumers.

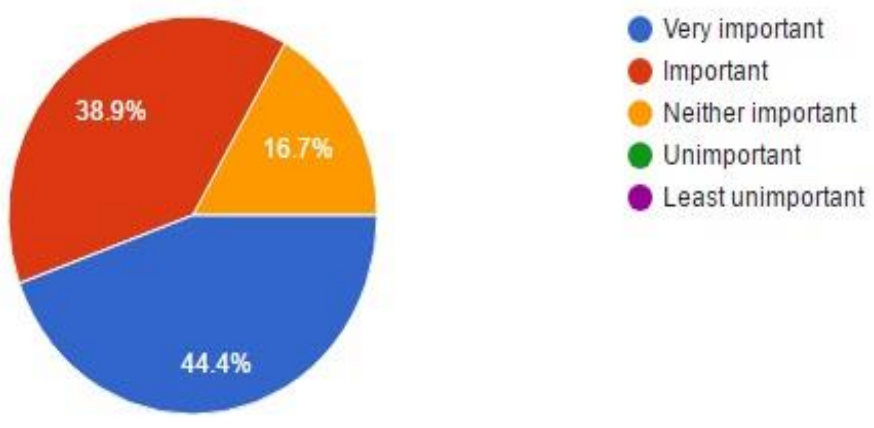

Figure 18: Fear of risk management challenges.

Customer Awareness: Awareness among consumers about the e-banking facilities and procedures is still at the lower side in the Indian scenario. Banks are not able to disseminate proper information about the use, benefits, and facility of internet banking. Less awareness of new technologies and their benefits is among one of the most ranked barriers in the development of e-banking.

Availability of Personnel services: In present times, banks are to provide several services like social banking with financial possibilities, selective up gradation, computerization and innovative mechanization, better customer services, effective 
managerial culture, internal supervision and control, adequate profitability, strong organization culture etc. Therefore, banks must be able to provide complete personnel service to the customers who come with expectations.

Implementation of global technology: There is a need to have an adequate level of infrastructure and human capacity building before the developing countries can adopt global technology for their local requirements. In developing countries, many consumers either do not trust or do not access to the necessary infrastructure to be able to process e-payments.

Handling Technology: Developing or acquiring the right technology, deploying it optimally and then leveraging it to the maximum extent is essential to achieve and maintain high service and efficiency standards while remaining cost effective and delivering a sustainable return to shareholders. Early adopters of technology acquire significant competitive advances Managing technology is, therefore, a key challenge for the Indian banking sector.

\section{Opportunities for the bankers}

Internet Banking: It is clear that online finance will pick up and there will be increasing convergence in terms of product offerings banking services, share trading, insurance, loans, based on the data warehousing and data mining technologies. Anytime anywhere banking will become common and will have to upscale, such upscaling could include banks launching separate internet banking services apart from traditional banking services.

Increasing Internet Users \& Computer Literacy: To use internet banking it is a very important requirement that people should have knowledge about internet technology so that they can easily adopt the internet banking services. The fast increasing internet users in India can be a very big opportunity and banking industry should encash this opportunity to attract more internet users to adopt internet banking services. There are $243,198,922$ Indians who are using the internet and it is increasing approximately 3.5 crores every year on an average. It also shows the rate of growth which is 168 percent since 2010. It is very much evident through the data provided by IAMAI (The Internet and Mobile Association of India). According to the ComScore Report, 2013 India is now world's third largest Internet user after U.S. and China. The computer literacy has gone upward in the last decade. Those with higher IT literacy may have a more positive perception towards e-banking in general and may thus, be more likely to accept ebanking services.

Worthy Customer Service: Worthy customer services are the best brand ambassador for any bank for growing its business. Every engagement with the customer is an opportunity to develop a customer faith in the bank. While increasing competition customer services has become the backbone for judging the performance of banks. 
Consumer expectations: These days it's all about the customer experience, and many banks are feeling pressure because they are not delivering the level of service that consumers are demanding, especially in regards to technology.

Indian Customers: The growing Indian banking sector with its strong home country linkages seek a unique combination of Indian ethnicity and global standards that offer valuable nice opportunities for Indian banks. The biggest opportunity for the Indian banking sector today is the Indian costumes. Demographic shifts in terms of income level and cultural shifts in terms of lifestyle aspirations are changing the profile of the Indian customer. This is and will be a key driver of economic growth going forward. The Indian customers now seek to fulfill his lifestyle aspirations at a younger age with an optimal combination of equity and debt to finance consumption and asset creation. The consumer represents a market for a wide range of products and services he need a mortgage to finance his house, an auto loan for his car, a credit card for on-going purchases, a bank account, a long-term investment plan to his children's higher education, pension plans for his retirement, a life insurance policy the possibilities are endless and this consumer does not live just in India's top ten cities. He represents across cities, towns, and villages i.e. in rural areas. Consumer goods companies are already tapping this potential it is for the banks to make the most of the opportunity to deliver solutions to this market.

Other Opportunities: a) To enter new business and new markets

b) To develop new ways of working

c) To improve efficiency

d) To deliver high level of customer services

\section{REFERENCES}

http://www.businessdictionary.com/definition/banking-system.html (meaning of E banking )

http://www.icommercecentral.com/open-access/the-electronic-banking-revolution-in-india.php?aid=59261

( evaluation of E banking in india ) Dhananjay B, Suresh CB (2015)

http://cis-india.org/raw/rbi-regulation-digital-financial-services-in-india-2012-2016 shivalik chandan (july

2016)

http://www.oneindia.com/feature/what-is-digital-india-programme-explained-1792279.html preeti panwar

(2015)

http://newscapture.in/everything-about-digital-india-mission/ (2016)

http://data.conferenceworld.in/ICRISMET/P931-937.pdf kumari nidhi (2016)

http://apeejay.edu/aitsm/journal/docs/issue-june-2015/ajmst020305.pdf vikas chauhan and vipin choudhary

file:///C:/Users/DOLPHIN/Downloads/Electronic\%20Banking\%20in\%20India-366.pdf Karamjit kaur (2014) http://apior.com/ijrp/downloads/091220147.pdf A. vennila 
http://vikalpa.com/pdf/articles/2003/2003 july sep 83 99.pdf SS kohli (2003)

http://www.wm2hm.com/category/banking-services/?gclid=CLrr3MbolNQCFdERaAodQ ol9w 